\title{
MEMANFAATKAN KAJIAN FONETIK UNTUK PENGEMBANGAN PEMBELAJARAN ILMU TAJWID*
}

\author{
Ahmad Sayuti Anshari Nasution \\ Universitas Islam Negeri Syarif Hidayatullah Jakarta \\ email : sayuti@uinjkt.ac.id
}

\begin{abstract}
Based on literary studies and empirical experience, this article aims to highlight the scientific facts that Tajwid (science of recitation of Holy Qur'an) met for change to be noted is subject to measure objectively, bursting capacity of self and non-precision and control, provided that this science that integrates the phonetics. Thus, the Tajwid be more popular if opened up to take advantage of explorations phonology and the science of medicine and anatomy, and other sciences. This article discusses several cases of voice and intonation issues in the science of scientific productions make it a more visible and controlled and subject to the measure if integrated with the Phonetics.
\end{abstract}

Keywords: phonetics, tajwid, science
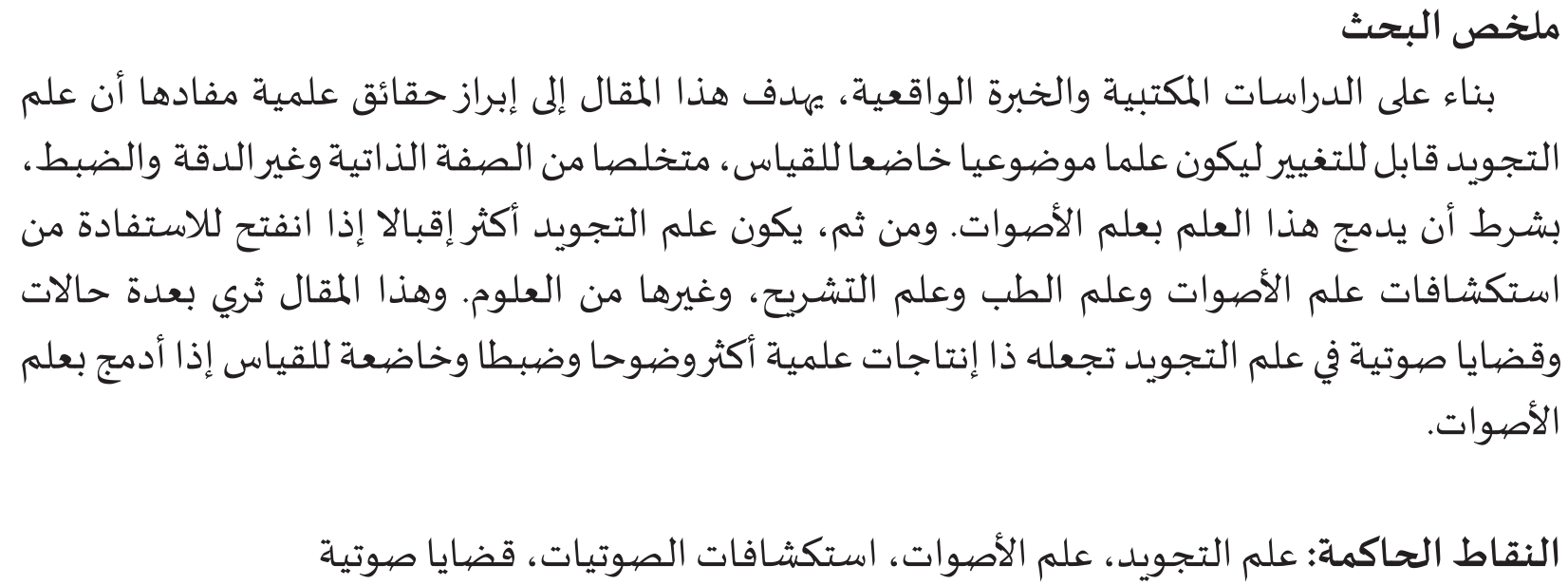

\begin{abstract}
Abstrak
Berbasis kajian literatur dan pengalaman empirik, tulisan ini bertujuan untuk menunjukkan bahwa ilmu tajwid bisa berubah menjadi ilmu yang bersifat objektif, terukur (pasti), dan terbebas dari sifat perkiraan subjektif, apabila disinergikan dengan ilmu fonetik. Karena itu, ilmu tajwid akan dapat lebih diterima, apabila membuka diri terhadap penemuan ilmu fonetik, ilmu kedokteran, ilmu anatomi, dan lain sebagainya. Kajian dalam tulisan ini diperkaya dengan sejumlah kasus/masalah dalam ilmu tajwid yang jika dipadukan dengan ilmu fonetik, produk keilmuannya menjadi lebih jelas, terukur, dan pasti.
\end{abstract}

Kata Kunci: ilmu tajwid, fonetik, bunyi, vokal kardinal 


\section{Pendahuluan}

Tajwid sebagai ilmu yang menuntun seseorang untuk dapat membaca alQur'an dengan baik, di mata sebagian besar umat Islam, dianggap sebagai ilmu klasik yang cukup dihafal dan diaplikasikan, tidak perlu dipahami. Ilmu ini merupakan ilmu yang dalam banyak hal mempunyai sifat subjektivitas tinggi, dan dalam pengakurasiannya terkesan tebaktebakan.

Ilmu tajwid dikatakan ilmu klasik karena ia lahir sejak beberapa abad yang lalu, atau persisnya pada abad III H. ketika Abu 'Ubaid Qâsim bin Salâm (w. 224 H) menerbitkan bukunya, al-Qirâ'ât, ${ }^{1}$ lalu disusul oleh Mûsa bin 'Abdullah bin Yahya al-Haqqani yang mempublikasikan antologi syairnya, Qashîdah al- $\underline{\text { Haqqâniyyah. }}{ }^{2}$

Selain klasik, ilmu tajwid juga sering diposisikan sebagai ilmu yang cukup dihafal karena ia merupakan kumpulan kaidah yang harus diaplikasikan. Para pelajar atau santri yang mengkaji ilmu tajwid tidak perlu memahami sebab atau alasan pengaplikasian ketentuan bacaan dalam ilmu tajwid. Selanjutnya, ilmu ini lebih dekat kepada seni atau keterampilan daripada ilmu murni. Tajwid hanya perlu penerapan bagaikanilmu-ilmu keterampilan lainnya, seperti keterampilan memasak, keterampilan menjahit, keterampilan musik, dan lain sebagainya.

Karena sifatnya praktis, ilmu tajwid dinilai bukan ilmu murni yang berkaitan dengan teori-teori yang bersumber dari nalar dan pengalaman hidup manusia, seperti ilmu-ilmu murni lainnya. Oleh sebab itu, tajwid sangat berbeda dari biologi, ilmu kimia, ilmu fisika, astronomi, dan ilmuilmu murni lainnya yang dalam banyak

1 Ibn al-Jazarî, al-Nasyr fî Qirâ'at al-'Asyr (Beirut: Dâr al-Fikr, tt), jil. I, tc, h. 24.

2 Ibid., h. 25. hal memerlukan nalar, dan sangat sedikit memerlukan hafalan.

Selanjutnya, ilmu tajwid dianggap bersifat subjektif dan tebak-tebakan karena karena dalam aplikasinya, selalu dapat ditemukan perbedaan akurasi bacaan antara dua atau beberapa orang. Contohnya, ketika dua orang membaca sebuah ayat al-Qur'an, maka akan terkesan terdapat perbedaan dalam akurasinya atau tidak selalu persis sama. Perbedaan yang terjadi bisa perbedaan tipis atau perbedaan yang signifikan, mulai dari penuturan bunyinya, panjang pendek, nada, intonasi bunyi yang dihasilkan, dan lain sebagainya.

Di lain pihak, ilmu fonetik merupakan ilmu murni yang bersifat objektif dan memerlukan nalar, serta produknya dapat diuji dengan alat-alat moderen seperti spektograph, kerongkongan imitasi, dan lain sebagainya. Dengan demikian, ilmu fonetik mirip dengan ilmu pasti yang tidak menggunakan perkiraan subjektif. Ilmu fonetik sangat membutuhkan daya nalar yang kuat dan proses aplikasi yang akurat sehingga produknya dapat diukur.

Tulisan ini berupaya membuktikan bahwa ilmu tajwid yang dianggap sebagai ilmu yang banyak mengandalkan perkiraan subjektif dapat berubah sifatnya menjadi ilmu yang objektif dan terukur (pasti) apabila disinergikan dengan aplikasi dan pengukuran dalam ilmu fonetik.

\section{Makhraj Bunyi}

Dalam mendeskripsikan makhraj dan sifat bunyi al-Qur'an, para ulama tajwid tidak menggunakan alat-alat bantu dan tidak memanfaatkan hasil penemuan dari ilmuwan lain. Hal ini berbeda dengan ilmu anatomi, fisika, kimia, dan ilmu pasti lainnya. Tanpa alatbantu atau pengukuran yang pasti, deskripsi hasil penelitian mereka dirasakan 
kurang aktual. Kita jarang menemukan buku tajwid yang menjelaskan tentang organ bicara secara detil, padahal sangat diperlukan dalam memahami makhraj dan sifat-sifat bunyi al-Qur'an.

Jika kita perhatikan cara Sibawaih (760796 M) - ulama yang menjadi imam ulama tajwid-dalam menentukan makhraj dan sifat bunyi dari organ bicara, khususnya dalam karyanya, al-Kitâb, Bâb al-Idghâm, maka dia sama sekali tidak mengemukakan sebuah gambar organ bicara pun, malah deskripsinya tentang organ bicara itu pun terkesan kurang akurat. Hal ini berbeda dengan Ibn Sina-inspirator ulama ilmu fonetik - yang menjelaskan organ bicara tersebut dengan mengemukakan gambar anatomi manusia sebagai hasil pengalamannya sebagai dokter. Deskripsi Ibnu Sina jelas lebih nyata dan pasti.

Definisi makhraj dari ulama tajwid terkesan kurang detil sehingga orang yang membaca al-Qur'an menganggap makhraj huruf sebagai sesuatu yang tidak pasti dan terkesan seperti tebak-tebakan. Ulama tajwid mendefinisikan makhraj sebagai "tempat keluarnya huruf dari mulut atau kerongkongan."3 Definisi ini sangat membingungkan. Karena itu, ada beberapa hal yang perlu dicermati dari definisi tersebut.

Pertama, penggunaan kata "huruf" kurang tepat dalam defenisi tersebut. Sebab, huruf adalah sejenis hasil seni yang keluar dari ujung pulpen atau kapur tulis dan ditangkap dengan mata. Dengan demikian, huruf itu makhraj-nya adalah di ujung pulpen, bukan di mulut atau kerongkongan. Seandainya definisi ini menggunakan kata bunyi, tentu akan lebih baik, karena bunyi adalah gejala alam yang keluar dari organ

\footnotetext{
3 Muhammad Abdel Azîz al-Hallâwi, Kaifa Tujawwid al-Qur'ân wa Turattiluhu Tartîlâ, (Kairo: Maktabah al-Qur'ân, 1984), h. 17.
}

bicara manusia dan ditangkap dengan telinga.

Kedua, perujukan tempat keluar, yakni "dari mulut atau kerongkongan" kurang akurat untuk definisi makhraj, karena makhraj merupakan point of articulation (titik artikulasi) yang posisinya bukan saja terdapat di mulut atau kerongkongan, melainkan juga di beberapa tempat lain, seperti di bibir, gigi, gusi, langit-langit lunak, langit-langit keras, anak lidah, dan tenggorokan.

Ketiga, definisi tersebut tidak menentukan secara persis titik tempat keluar sebuah bunyi, karena hanya menyebutkan satu organ bicara saja tanpa pasangan, dan tanpa menentukan di bagian mana dari organ bicara tersebut bunyi itu keluar, sementara organ bicara itu luas dan panjang. Panjang kerongkongan, misalnya, dimulai dari atas tenggorokan sampai pangkal langit-langit lunak. Demikian pula panjang mulut, dimulai dari kerongkongan sampai ke gigi dan bibir.

Ulama tajwid membagi konsonan ke dalam tujuh makhraj utama, sesuai dengan tujuh organ bicara yang menjadi makhrajnya sebagai berikut:

\section{Konsonan labial (شـفــــة)}

2. Konsonan dental (أسـنانية)

3. Konsonan alveolar (لثوية)

4. Konsonan palatal (طبقية) (لنوية)

5. Konsonan velar (حنـكية)

6. Konsonan uvular (لكهويـة)

7. Konsonan pharyngal (حلقية)

Ketujuh organ bicara di atas sebenarnya masih dapat dibagi-bagi lagi. Gigi, umpamanya, bisa dibagi ke dalam: (1) pangkal gigi, (2) tengah gigi, dan (3) ujung gigi. Demikian juga dengan semua organ bicara lainnya yang masih bisa dibagi-bagi ke dalam bagian yang lebih kecil untuk 
menentukan titik makhraj sebuah bunyi secara lebih tepat dan akurat.

Makhraj dalam fonetik didefinisikan sebagai "tempat tertentu di saluran udara yang merupakan titik kerjasama antara dua organ bicara, yang satu aktif dan yang kedua pasif."4 Yang dimaksud dengan organ bicara aktif adalah organ bicara yang bergerak mendatangi organ bicara pasif, seperti bibir bawah (labial), ujung lidah (apico), tengah lidah (medio), pinggir lidah (lamino), dan belakang lidah (dorso).

Dari definisi ini, fonetik membagi makhraj ke dalam 11 konsonan titik artikulasi berikut:

1. Konsonan bilabials (dua bibir), yang terdiri dari: ب، م، و

2. Konsonan labio-dental (bibir + gigi), ف : yang terdiri dari

3. Konsonan apico interdental (ujung lidah + ujung gigi), yang terdiri dari: ث، ذ، ظ

4. Konsonan apico-dental (ujung lidah + ت، ط، د، : pangkal gigi), yang terdiri dari ض، ل، ن

5. Konsonan apico-alveolar (ujung lidah + ر، س، ص، ز : gusi), yang terdiri dari

6. Konsonan apico-palatal (ujung lidah + langit-langit keras), yang terdiri dari: ش، ج

7. Konsonan medio-palatal (tengah lidah + langit-langit keras), yang terdiri dari:

8. Konsonan dorso-velar (pangkal lidah + langit-langit lunak), yang terdiri drai: $\dot{\tau} \cdot \dot{\varepsilon} \cdot$ ك

9. Konsonan dorso uvular (pangkal lidah + anak lidah), yang terdiri dari: ق

10. Konsonan dorso pharyngal (pangkal lidah + kerongkongan), yang terdiri dari, $\tau$, $\varepsilon$

4 Kamâl Muhammad Bisyr, al-Ashwât alArabiyah (Kairo: Maktabah al-Syabâb, 1991), h. 89.
11. Konosnan glottal (dua buah pita suara), yang terdiri dari: هـ . s. 5 .

Jika kita lihat penentuan titik artikulasi (makhraj) di dalam definisi di atas, kita bisa melihat batasan yang akurat, sehingga tidak perlu meraba-raba dan menebaknebak. Sebab, dalam definisi itu disebutkan dua organ bicara yang bekerjasama untuk memproduk sebuah bunyi tertentu, sehingga tidak bisa melebar dan memanjang ke mana-mana.

Untuk membuktikan hal tersebut, kita bisa menuturkan sebuah bunyi yang kita ingin tahu makhraj-nya, misalnya / $/$ /, tanpa diikuti dengan harakat lain berkali-kali, lalu kita perhatikan bahwa ada dua organ bicara sedang bekerja sama memproduksi bunyi itu, yaitu ujung lidah dengan pangkal gigi. Dengan demikian, "ujung lidah dengan pangkal gigi" itu adalah makhraj /ت/. Siapa pun yang menuturkannya dan di mana pun dituturkan, pasti hasil yang akan muncul seperti /ت/ itu.

\section{Sifat Bunyi}

Ada beberapa sifat bunyi yang disebutkan dalam ilmu tajwid dan fonetik. Meski istilahnya berbeda, namun substansinya hampir sama. Akan tetapi, yang akan dijelaskan dalam tulisan ini hanya 4 (empat) sifat saja, yaitu bersuara, tidak bersuara, letupan, dan geseran.

\section{Bunyi Bersuara}

Bunyi bersuara di dalam ilmu tajwid dipopulerkan dengan huruf majhûr. Bunyi ini tampaknya hanya sekadar hafalan para santri, tidak pernah dijelaskan bagaimana cara memproduknya dan tidak mempunyai ukuran apakah tuturan santri sudah

5 Sâmi Ayâd Hanna, Mabâdi' 'Ilm al-Lisâniyât

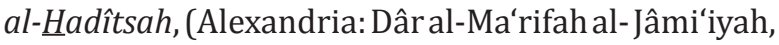
1991), h. 232. 
benar atau belum. Lebih ironis lagi, banyak guru tajwid yang tidak mengerti cara memproduk bunyi jahr dan cara membedakannya dengan bunyi hams.

Di dalam ilmu tajwid, bunyi bersuara atau jahr didefinisikan dengan "bunyi yang kuat, yang ketika dituturkan, napas terhalang keluar bersamanya"6. Di antara bunyi bersuara adalah

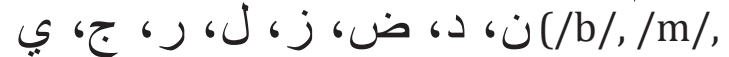
/w/, /n/, /d/, /dh/, /z/, /l/, /r/, /j/, $/ \mathrm{y} / \mathrm{s}$.

Dari definisi bunyi bersuara di atas, dapat dipahami bahwa yang terhalang keluar adalah napas. Hal ini diakibatkan oleh bunyi yang terlalu kuat bergantung di makhraj. Padahal, yang mengalami kesulitan keluar akibat dua buah pita suara yang posisinya terlalu berdekatan adalah bunyi sehingga ketika bunyi itu keluar mengakibatkan terjadinya getaran.

Karena ulama tajwid tidak menyebutkan sama sekali peranan dua pita suara, atau organ bicara lain dalam pembentukan bunyi bersuara ini, maka sulit bagi seorang peneliti untuk mendeteksi bunyi-bunyi bersuara tersebut. Inilah yang menyebabkan peneliti harus melakukan perkiraan subjektif dalam menentukan bunyibunyi bersuara itu.

Definisi bunyi bersuara ulama tajwid juga rancu dengan definisibunyi letupan. Bunyi letupan didefinisikan sebagai bunyi yang terjadi akibat hambatan kuat yang terjadi pada saluran udara yang menghambat perjalanan udara yang keluar dari paru-paru. ${ }^{7}$ Kerancuan definisi bunyi bersuara dengan bunyi letupan ini turut mempersulit para

6 Ibn al-Jazarî, op. cit., h. 97.

7 Tagrid Sa'id Anbar, Dirâsat Shautiyyah (Tunis: ALESCO, 1990), jilid I, h. 198-225. santri dan peneliti untuk mendeteksi bunyi bersuara itu secara tepat dan pasti, dan pada akhirnya harus melakukan perkiraan subjektif.

Adapun bunyi bersuara dalam ilmu fonetik didefinisikan sebagai bunyi bergetar yang terjadi akibat mendekat dan menjauhnya dua buah pita suara di kerongkongan secara berulang-ulang. ${ }^{8}$ م، ب،:Di antara bunyi bersuara adalah  zh/, /z/, /l/). Definisi ini lebih jelas dan dapat dibuktikan dengan pengukuran yang akurat.

\section{Bunyi Tidak Bersuara}

Bunyi tidak bersuara di dalam ilmu tajwid dipopulerkan dengan huruf mahmûsah yang didefinisikan sebagai "bunyi yang lemah, yang ketika dituturkan, napas tidak terhalang keluar bersamanya." Di antara bunyi yang س، ك، ت، ف، ح، (/t/, /f/, / / /, /ts/, /h/, /sy/, /kh/, /sh/, /s/, /k/).

Dari definisi tersebut, dapat ditegaskan tiga catatan, yaitu: (1) yang terhalang keluar adalah napas, bukan bunyi; (2) definisi bunyi ini tidak menyebutkan sama sekali peranan dua pita suara, atau organ bicara lain dalam pembentukan bunyi tidak bersuara ini; (3) definisi bunyi tidak bersuara akan rancu dengan definisi bunyi geseran. Dalam hal ini, bunyi geseran didefinisikan sebagai bunyi yang terus meluncur akibat hambatan lemah yang terjadi pada saluran udara yang keluar dari paru-paru atau adanya saluran lain yang tidak menghalangi udara keluar. ${ }^{10}$ Tiga catatan di atas mengakibatkan

$8 \quad$ Kamâl Muhammad Bisyr, op. cit., h. 88.

9 Ibn al-Jazarî̀, loc. cit.

10 Tagrid Said Anbar, op. cit., h. 198-225. 
santri dan peneliti tidak bisa mendeteksi bunyi tidak bersuara itu secara tepat dan pasti tetapi harus melakukan perkiraan subjektif.

Adapun bunyi tidak bersuara dalam ilmu fonetik didefinisikan sebagai bunyi yang terjadi ketika dua buah pita suara dalam keadaan berjauhan sehingga tidak terjadi getaran di kerongkongan ketika bunyi itu dituturkan. ${ }^{11}$ Di antara bunyi tidak bersuara adalah: شح، ك، ش، ث، صك (/s/, /sy/, /ts/, /sh/, /k/, /h/, /kh/).

Di dalam ilmu fonetik, untuk mengetahui suatu bunyi bersuara atau tidak, dapat dilakukan salah satu cara berikut: (1) menutup kedua telinga dengan jari-tangan kemudian menuturkan bunyi yang dimaksud tanpa disertai bunyi lain; (2) meletakkan jari di lekum (apel adam) kemudian menuturkan bunyi yang dimaksud tanpa disertai bunyi lain; dan (3) meletakkan telapak tangan di ubun-ubun kemudian menuturkan bunyi yang dimaksud tanpa disertai bunyi lain.

Apabila kita mendapatkan getaran di ujung jari atau telapak tangan, maka kita pastikan bahwa bunyi itu adalah bunyi bersuara. Sebaliknya, apabila tidak ada getaran, maka kita pastikan bunyi tersebut adalah bunyi tidak bersuara. Karena definisi bunyi bersuara atau tak bersuara cukup jelas dan dapat diuji secara akurat, maka memproduksi dan membedakan antara bunyi bersuara dengan bunyi tidak bersuara dapat dibuktikan dengan pasti.

\section{Bunyi Letupan}

Bunyi letupan dalam ilmu tajwid dipopulerkan dengan syadîdah. Definisi

\footnotetext{
11 Kamâl Muhammad Bisyr, ibid.
}

syadîdah adalah huruf yang mempunyai keterikatan kuat dengan makhraj-nya sehingga bunyi yang akan dituturkan mengalami hambatan untuk keluar karena terdapat ketergantungan yang kuat terhadap makhraj. ${ }^{12}$ Di antara ق، ط، ب، ج، د،

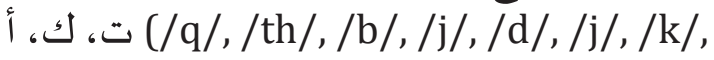
/ /).

Mencermati definisi di atas, terdapat duahalyang rancu,yaitu:(1)penggunaan kata huruf yang tidak tepat karena yang didefinisikan adalah bunyi bukan huruf; (2) huruf yang sulit keluar ketika dituturkan karena ketergantungannya yang kuat dengan makhraj. Pernyataan ini sulit dipahami, mungkin lebih mudah dipahami kalau diubah menjadi sulitnya bunyi keluar ketika dituturkan karena adanya hambatan yang kuat di makhraj. Dan, hal ini membuat ketidakpastian yang dapat memaksa peneliti untuk melakukan perkiraan yang subjektif.

Sedangkan, dalam ilmu fonetik, bunyi letupan didefinisikan sebagai bunyi yang terjadi akibat hambatan kuat yang terjadi pada saluran udara yang menghambat jalannya udara yang keluar dari paru-paru, ${ }^{13}$ sehingga ketika hambatan tersebut terbuka, akan terdengar bunyi seperti bunyi letupan. ق،: Di antara bunyi syadidah adalah ق. ط، ب، ج، د، ت، ك، أ Definisi ini lebih jelas dan dapat dibuktikan dengan pengukuran yang akurat.

\section{Bunyi Geseran}

Bunyi geseran dalam ilmu tajwid dipopulerkan dengan rakhwah. Rakhwah didefinisikan sebagai huruf

12 Muhammad al-Shâdeq Qamhâwî, al-Burhân fî Tajwîd al-Qur'ân wa Fadhâ'il al-Qur'ân (Kairo: Maktabah al-Kulliyat al-Azhariyah, 1978), h. 23.

13 Tagrid Sa'id Anbar, op. cit, h. 198-225. 
yang tidak mempunyai keterikatan kuat dengan makhraj-nya sehingga bunyi tersebut meluncur dengan mudah ketika dituturkan karena lemahnya keterikatan dengan makhraj. ${ }^{14}$ Di antara م، ف، ذ، ظ، س، bunyi geseran adalah  /s/, /sh/, /l/, /n/, /r/). Terkait definisi bunyi geseran ini, penulis menilai masih terdapat kerancuan sebagaimana pada definisi bunyi letupan.

Sebaliknya, bunyi geseran di dalam ilmu fonetik didefinisikan sebagai bunyi yang terus meluncur akibat lemahnya hambatan yang terjadi pada saluran udara yang menghambat keluarnya udara dari paru-paru. ${ }^{15}$ Di antara bunyi م، ف، ذ، ظ، س، ص، ل، geseran adalah (/zh/, /s/, /sh/, /l/, /n/, /r/, /y/, /m/, /f/, /dz/).

Untuk mendeteksi kedua bunyi ini, dapat dilakukan dengan cara menuturkan bunyi yang akan ditentukan sifatnya dengan tanpa harakat kemudian membiarkannya untuk sekian waktu tanpa melepaskan makhraj-nya. Apabila udara terasa tidak bisa keluar dan napas pun menjadi terganggu, maka dapat dipastikan bahwa bunyi itu adalah bunyi letupan. Sebaliknya, apabila bunyi tersebutdituturkan tanpa harakatuntuk beberapa saat, tetapi bunyi tersebut tetap bergeser dan pernapasan pun tidak terganggu, maka dapat dipastikan bunyi itu bunyi geseran.

Dari definisi yang sangat jelas dan dengan cara pengujian yang akurat, maka memproduksi dan membedakan antara bunyi letupan dan bunyi geseran menjadi nyata dan dapat dibuktikan secara pasti.

14 Ibid.

15 Ibid.

\section{Bunyi Oral, Nasal, dan Oronasal}

Apabila dilihat dari saluran yang dilalui sebuah bunyi ketika diartikulasikan, ilmu fonetik membagi bunyi menjadi tiga, yaitu: bunyi oral, bunyi nasal dan bunyi oronasal. Akan tetapi, ilmu tajwid tampaknya hanya membaginya menjadi dua bagian saja, yaitu: bunyi oral dan ghunnah, walaupun dalam kenyataannya bunyi oronasal juga terdapat di dalam tajwid.

Khusus mengenai bunyi oral, mungkin ilmu tajwid dan fonetik tidak terlalu berbeda dalam memaknainya, yaitu bunyi yang ketika diartikulasikan, rongga hidung tidak berfungsi sebagai tempat keluar udara akibat naiknya langit-langit lunak atau anak lidah yang menutup pintu udara dari rongga mulut ke rongga hidung sehingga udara semua keluar dari rongga mulut. ${ }^{16}$ Bunyiب، ف، و، ذ، ظ، : bunyi oral antara lain adalah: (/b/, /f/, /w/, /dz/, /zh/, /t/, /th/, /d/, /dh/, /s/, /sy/, /sh/).

Ilmu tajwid menyebut bunyi nasal dengan ghunnah dan mendefinisikannya sebagai bunyi yang indah, yang keluar dari rongga hidung (khaisyûm) yang menempel pada bunyi mîm dan nûn. ${ }^{17}$ Definisi ini tidak mengandung kerancuan karena ilmu fonetik pun mendefinisikan bunyi nasal sebagai bunyi yang ketika diartikulasikan, rongga hidung berfungsi sebagai tempat keluar udara, akibat langit-langit lunak atau anak lidah turun, sehingga pintu udara dari rongga mulut ke rongga hidung terbuka dan udara pun keluar lewat rongga hidung yang terbuka tersebut. ${ }^{18}$

Akan tetapi, terdapat perbedaan pada pendefinisian bunyi oronasal antara

16 Muhammad Ali al-Khûlî, Mu'jam 'Ilm alAshwât (Riyadh: Maktabah al-Farazdaq, 1982), h. 107.

17 Kamâl Muhammad al-Mahdî, Tajwîd alQur'ân (Kairo: Dâr al-Taufîq, 1988), h. 155.

18 Muhammad Ali al-Khuli, op. cit, h. 31. 
ilmu tajwid dan fonetik. Ilmu fonetik mengemukakan bunyi oronasal dan mendefinisikannya dengan bunyi yang sebagian udaranya keluar dari rongga mulut dan sebagian yang lain keluar dari rongga hidung, seperti bunyi paduan dari nûn dan yâ pada kalimat مَنْ يَعْمَلْ (may/-ya'/mal). Sedangkan, penamaan bunyi nasal dengan bunyi ghunnah seperti yang dilakukan ulama tajwid perlu ditinjau ulang karena tidak membedakan antara bunyi nasal (mîm dan nûn) dengan bunyi ghunnah yang merupakan paduan dari bunyi mîm dan nûn ketika bertemu dengan bunyi-bunyi ghunnah.

Untuk memastikan sebuah bunyi nasal, oral, atau oronasal, ilmu fonetik merekomendasikan untuk menuturkan bunyi yang sedang dicari jenisnya kemudian menutup hidung. Indikatornya, jika bunyi tidak berubah, maka bunyi tersebut adalah bunyi oral. Akan tetapi, jika berubah atau terhenti, maka bunyi tersebut adalah bunyi nasal.

Dari definisi yang sangat jelas dan dengan cara pengujian yang akurat, maka memproduksi dan membedakan antara bunyi oral, nasal, dan oronasal menjadi nyata dan dibuktikan dengan pengukuran yang pasti.

\section{Bunyi Tebal dan Bunyi Tipis}

Dalam ilmu tajwid, bunyi tebal disebut dengan bunyi tafkhîm. Tafkhîm adalah penggemukan bunyi dengan cara menggemukkannya ketika diartikulasikan dan membuatnya menjadi lebih kuat. $^{19}$ Sedangkan, bunyi tipis disebut dengan bunyi tarqîq. Tarqîq ialah penipisan bunyi dengan cara menipiskannya ketika diartikulasikan dan membuatnya menjadi lemah. ${ }^{20}$

19 Ahmad Syirbiny Sa'udî, al-Fajr al-Jadîd fî 'Ilm al-Tajwîd (Kairo: Dâr al-Manâr, 1990), h. 85.

20 Ahmad Syirbiny Sa'udî, ibid.
Tarqîq dan tafkhîm adalah dua masalah yang sangat sulit dipahami dalam mempelajari bacaan al-Qur'an. Sebab, definisiyang dibuat pakarilmu tajwid kurang jelas sehingga santri yang mempelajarinya pun menemui kesulitan. Kekurangjelasan ini pada akhirnya mengakibatkan santri melakukan perkiraan subjektif dalam menuturkannya.

Sebaliknya, ilmu fonetik menjelaskan cara memproduksi bunyi tebal dan tipis secara gamblang. Bunyi tafkhîm (tebal) adalah bunyi yang ketika diartikulasikan menjadi tebal akibat pangkal lidah dinaikkan ke atas, ke arah langit-langit lunak. Sedangkan bunyi tarqîq (tipis) adalah bunyi yang ketika diartikulasikan menjadi tipis akibat pangkal lidah diturunkan ke bawah ke dasar mulut. ${ }^{21}$

Berdasarkan penelitian para pakar, ilmu fonetik menetapkan bahwa dalam pembentukan sebuah bunyi tebal (tafkhîm), pangkal lidah harus dinaikkan ke atas. Inilah satu-satunya yang dapat membedakan antara bunyi tebal (tafkhîm) dengan bunyi tipis (tarqîq)..$^{22}$ Bunyi sîn dan dzâl, umpamanya, adalah bunyi muraqqaq (dibaca tipis). Artinya, ketika menuturkan sîn atau dzâl, pangkal lidah tidak dinaikkan ke atas. Apabila menuturkan sîn dengan cara pangkal lidah dinaikkan ke atas, maka ia segera berubah menjadi shâd yang merupakan tafkhîm dari sîn. Begitu juga dzâl dituturkan dengan tidak menaikkan pangkal lidah ke atas. Ketika menuturkan dzâl dengan cara pangkal lidah dinaikkan ke atas, maka ia segera berubah menjadi zhâ' yang merupakan tafkhîm dari dzâl.

Sesuai ketentuan dalam ilmu tajwid, apabila huruf lâm atau râ' tidak ber-harakat kasrah, sedangkan bunyi huruf sebelumnya

21 Kamâl Muhammad Bisyr, op. cit, h. 102.

22 Lihat Kamal Muhammad Bisyr, ibid. 
adalah fathah, maka huruf lâm atau râ itu harus dituturkan tebal (tafkhîm). Karena itu, pada kasus huruf lâm lafazh al-Jalâlah (Allâh), santri atau yang belajar membaca al-Qur'an dengan mudah memproduksinya sebagai bunyi tebal (tafkhîm) dengan cara mengangkat pangkal lidahnya ke arah langit-langit lunak.

Apabila ketentuan ilmu tajwid ini dipadukan dengan pengukuran dalam ilmu fonetik, maka produknya dapat dibuktikan secara konkret. Hal ini karena definisi tebal dan tipis di dalam ilmu fonetik sangat jelas dan dapat diaplikasikan secara mudah. Siapa saja dan di mana saja dapat memproduksinya dengan tepat, tanpa harus melakukan perkiraan subjektif.

\section{Imâlah dan Fath (Tahqîq)}

Imâlah adalah pergeseran dari fath murni (tahqî́q) ke arah kasrah. Para penulis kitab qirâ'at menerangkan bahwa maksud fath di sini bukan harakat yang populer diketahui dalam bahasa Arab, yaitu fathah, kasrah, dan dhammah. Sebab, fathah dan alif dalam kajian linguistik adalah samasama vokal yang tidak bisa menerima vokal lagi. Para penyusun dan pensyarah buku tajwid/qirâ'at selanjutnya menambahkan bahwa yang dimaksud dengan fath adalah membuka mulut (kedua bibir) ketika menuturkan alif. $^{23}$

Fenomena fath dan imâlah berasal dari kebiasaan berbahasa yang samasama populer di Jazirah Arab. Fenomena fath populer di kalangan penduduk Hijaz, termasuk suku Quraisy, sedangkan fenomena imâlah populer di kalangan

23 'Abdul Fattâh Abdul Ghanî al-Qâdhî, al-Wâfî fî Syarh al-Syâthibiyyah fî al-Qirâ'at al-Sab' (al-Madinah al-Munawwarah: Maktabah al-Dâr, 1989) cet. II, h. 140. Lihat juga Ahmad Fathoni, Kaidah Qiraat Tujuh (Jakarta: PTIQ 2005), h. 28. penduduk pedalaman, termasuk Najd dan Tamim. ${ }^{24}$

Di dalam ilmu tajwid/qirâ'at, imâlah terbagi menjadi dua bagian, yaitu imâlah kubrâ (mayor) dan imâlah shughra (minor). Imâlah kubrâ (mayor) ialah menuturkan fathah mirip dengan kasrah, atau alif mirip dengan yâ. Artinya bahwa alif tidak sampai diganti menjadi yâ secara murni dan juga tidak ditebalkan berlebihan. ${ }^{25}$ Imâlah seperti ini disebut juga dengan imâlah murni atau idjâ'.

Imâlah shughrâ (minor) ialah menuturkan fathah antara fathah murni dengan imâlah kubrâ. ${ }^{26}$ Imâlah seperti ini disebut juga dengan istilah taqlîl (pengurangan) karena keterbukaan mulut dikurangi atau ketebalannya dikurangi dari keterbukaan imâlah tafkhîm. Imâlah ini disebut baina baina (tengah-tengah) karena ia berada di tengah-tengah antara fathah murni dengan imâlah kubrâ.

Tampaknya para pengarang dan pensyarah buku tajwid/qirâ'at merasa sulit menjelaskan bagaimana menuturkan imâlah kubrâ dan imâlah sughrâ tersebut de-ngan benar dan bagaimana membedakan antara bacaan yang satu dengan bacaan yang lain. Kondisi ini menyebabkan sebagian penyusun tajwid/qirâ'at menerangkan bahwa untuk mengetahui penuturannya (imâlah) yang tepat, diharuskan belajar secara talaqqî (tatap muka) atau mendengarkan kaset rekaman beberapa orang qâri' yang sudah terkenal. ${ }^{27}$ Keterangan seperti ini menunjukkan bahwa mereka tidak berusaha memberikan gambaran dan penuturannya secara konkret.

\footnotetext{
h. 14 .

25 'Abdul Fattâh Abdul Ghanî al-Qâdhî, op. cit. h. 140. Lihat juga Ahmad Fathoni, loc. cit.

26 Ibid.

27 Ahmad Fathoni, loc. cit.
}

24 Muhammad Shadeq Qamhâwî, op. cit, 
Imâlah sebenarnya sudah menjadi fenomena umum di berbagai bahasa, termasuk bahasa Indonesia dan bahasa Arab. Penyebab terjadinya imâlah dalam tinjauan fonetik adalah karena adanya tarikmenarik antara dua vokal yang berbeda, seperti tarik- menarik antara fathah (a) dengan kasrah (i) pada kata صباح الخَير (shabâh al-khair) yang mana antara (a) dengan (i) pada kata الخَير (khair) terjadi tarik-menarik. Sebagian besar penduduk Arab sekarang sudah menuturkannya dengan imâlah sehingga menjadi (shabâh al-kheer) bukan lagi (shabâh al-khair). Jadi, imâlah menurut fonetik sesungguhnya terjadi sebagai kompromi (win-win sulution) atas terjadinya tarik-menarik antara fathah (a) dengan kasrah (i) sehingga yang terjadi bukan fathah dan bukan kasrah, melainkan yang terjadi adalah bunyi lain yaitu (e). ${ }^{28}$

Dalam bahasa Indonesia, fenomena tarik-menarik antara (a) dengan (i) ini sudah populer. Contohnya, kata tapai dan tupai yang dituturkan oleh warga Indonesia dengan imâlah sehingga menjadi tape dan tupe. Oleh sebab itu, mengajari penduduk Indonesia menuturkan imâlah tidaklah sesulit yang dibayangkan para penulis buku qirâ'at, yang harus dilakukan dengan tatap muka dan mendengarkan kaset rekaman ahli. Sebab, imâlah tersebut banyak terdapat di dalam bahasa Indonesia dan telah diaplikasikan secara nyata di dalam pembicaraan sehari-hari.

Fenomena imâlah sesungguhnya muncul sebagai upaya memberikan kesan bahwa pada kata itu terdapat $y \hat{a}$, yang tidak selayaknya diabaikan seperti yang dilakukan oleh dialek Hijaz, yang langsung menuturkannya dengan fathah murni. Contohnya, kata هدى (hudâ[y]).

28 Ahmad Sayuti Anshari Nasution, Bunyi Bahasa (Jakarta: Amzah, 2009), h. 93.
Alif maqshûrah (yang dibaca a) di akhir kata tersebut sebenarnya berasal dari yâ sukûn (yang dibaca mirip kasrah [i]) akan tetapi untuk mencocokkan dengan dâl, bunyi kasrah [i] diganti dengan vokal fathah (a). Dalam kondisi ini, fathah akan lebih cocok bila berpasangan dengan alif sehingga menjadi mad, dibandingkan kalau berpasangan dengan yâ yang menyebabkan perpindahan gerak lidah dan bibir dari satu posisi ke posisi lain.

Lebih dari fenomena imâlah di dalam ilmu qirâ'at yang hanya terjadi pada tarikmenarik antara vokal fathah dengan vokal kasrah, imâlah dalam pembicaraan seharihari juga terjadi pada tarik-menarik antara vokal fathah dengan vokal dhammah.

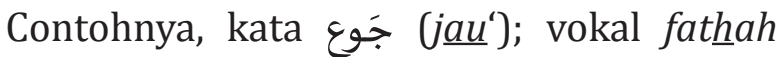
pada jîm ditarik oleh dhammah yang terjelma dalam waw. Mayoritas penduduk Arab membacanya dengan imâlah antara fathah dengan dhammah, yaitu vokal (o) sehingga dibaca menjadi (jo').

Di dalam bahasa Indonesia, fenomena tarik-menarik antara vokal (a) dengan vokal (u) sudah sangat populer. Contohnya, kata surau dan harimau. Pada kasus ini, warga Indonesia menuturkannya langsung menjadi suro dan harimo.

Dalam memproduksi sebuah vokal, bentuk bibir tidak dapat diabaikan. Sebab, perbedaan bentuk bibir ketika menuturkan sebuah vokal akan menentukan jenis vokal itu sendiri. ${ }^{29}$ Secara umum, ada tiga bentuk bibir yang dominan dalam menentukan suatu vokal, yaitu: (1) posisi membulat yang dominan dalam menuturkan vokal dhammah (u), (2) posisi membentang yang dominan dalam menuturkan vokal kasrah (i), dan (3) posisi terbuka yang dominan

29 Kamâl Muhammad Bisyr, op. cit., h. 143. Lihat juga Abdullah Rabi' Mahmûd, 'Ilm al- Shautiyyât (Makkah: Maktabah al-Thalib al-Jâmi'iy, 1988), h. 195. 
dalam menentukan vokal fathah (a). Posisi yang terakhir ini dimaksudkan ulama qirâ'at dengan istilah fath yang bukan harakat.

Di samping tiga bentuk utama kedua bibir di atas, terdapat juga bentuk cabang, seperti posisi semi membulat untuk menuturkan vokal (o) dalam kata obat, semi membentang untuk menuturkan vokal (e) dalam kata ekor, dan semi membuka untuk menuturkan vokal ( $\Sigma$ ) dalam kata emas, dan vokal (ગ) dalam kata rokวk

Ketika pengarang ilmu qirâ'at berbicara tentang pembentukan imâlah kubrâ (mayor) dan imâlah sughrâ (minor), terkesan mereka mendapat kesulitan untuk menjelaskannya karena mereka tidak menjelaskan bentuk kedua bibir dengan detil. Mereka mendefiniskan imâlah kubrâ sebagai "menuturkan fathah dekat dengan kasrah, dan alif dekat dengan yâ". Sedangkan, imâlah sughrâ didefinisikan sebagai "menuturkan fathah antara fathah dengan imâlah kubrâ".

Dua buah definisi di atas tampaknya tidak mudah dipahami sehingga perlu dikompromikan dengan definisi yang lebih jelas dan mudah dipahami dari ilmu fonetik. Dengan demikian, akan lebih tepat apabila definsi imâlah kubrâ adalah menuturkan fathah dengan bentuk kedua bibir semi membentang, sedangkan imâlah sughrâ adalah menuturkan fathah dengan bentuk kedua bibir semi membuka.

Dalam memproduksi vokal, bagian lidah yang bergerak ketika menuturkan sebuah vokal tidak dapat dilupakan, karena bagian lidah yang bekerja sama dengan kedua bibir inilah yang sesungguhnya membentuk vokal itu. ${ }^{30}$ Dalam pembentukan vokal, ilmu fonetik membagi lidah ke dalam tiga bagian, yaitu: (1) bagian depan yang merupakan

30 Kamâl Muhammad Bisyr, loc. cit. Lihat juga Abdullah Rabi' Maي̣mûd, loc. cit. bagian lidah yang berpengaruh dalam pembentukan vokal (i, e, $\Sigma$ dan a), (2) bagian belakang lidah yang berpengaruh dalam pembentukan vokal $(a, \mathrm{~J}, \mathrm{o}$, dan $\mathrm{u})$, dan (3) bagian tengah lidah yang berpengaruh dalam pembentukan vokal qalqalah.

Dalam menjelaskan vokal, ilmu fonetik biasanya menyajikan bagan mulut yang digunakan lidah dalam memproduksi vokal yang populer disebut dengan vokal cardinal. Untuk lebih jelasnya, berikut ini disampaikan standar vokal yang menggambarkan mulut tempat vokal itu diartikulasikan. ${ }^{31}$

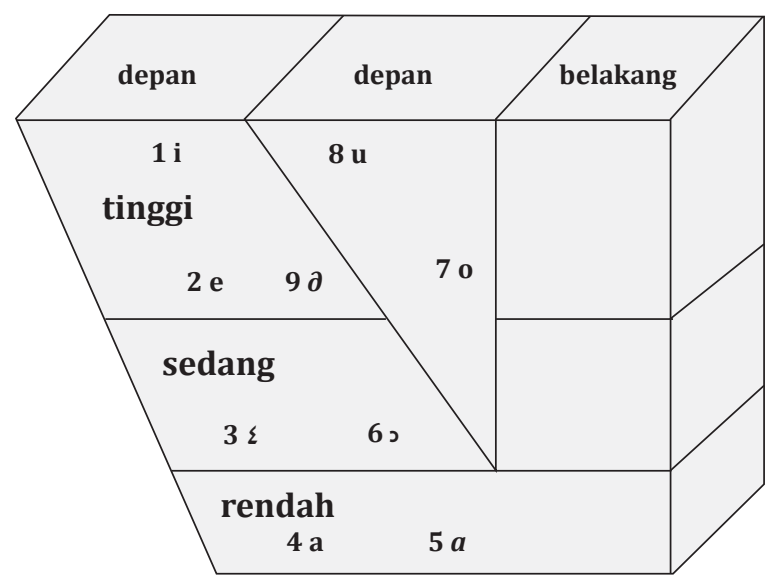

Standar vokal (vocal cardinal) yang diciptakan oleh Daniel Jones ini bersifat umum. Semua vokal dalam bahasa mana saja dapat menggunakannya sebagai acuan, dan semua vokal yang ingin diteliti dapat diukur dengan menggunakan standar itu.

Deskripsi sembilan vokal kardinal adalah sebagai berikut:

1. Standar I. Vokal ini dibentuk dengan menaikkan bagian depan lidah ke arah langit-langit setinggi mungkin, dan bibir membentang. Standar I ini menghasilkan sebuah bunyi yang diberi lambang /i/.

2. Standar II. Vokal ini dibentuk dengan menaikkan bagian depan lidah ke arah langit-langit tetapi lebih rendah dari

\footnotetext{
31 Kamâl Muhammad Bisyr, op. cit., h. 139
} 
standar I, kira-kira 1/3, sedangkan bibir berada dalam posisi semi membentang. Standar ini menghasilkan vokal yang diberi lambang /e/. Vokal inilah yang dimaksud dengan imâlah kubrâ.

3. Standar III. Vokal ini dibentuk dengan menaikkan bagian depan lidah ke arah langit-langit tetapi lebih rendah dari standar II, kira-kira 1/3, sedangkan bibir berada dalam posisi semi membentang. Standar ini menghasilkan vokal yang diberi lambang /4/. Vokal inilah yang dimaksud dengan imâlah shughrâ.

4. Standar IV. Vokal ini dibentuk dengan menurunkan bagian depan lidah ke arah dasar mulut serendah mungkin, sedangkan bibir berada dalam posisi netral. Standar ini menghasilkan vokal yang diberi lambang /a/. Vokal inilah yang disebut dengan istilah fath .

5. Standar V. Vokal ini dibentuk dengan menurunkan bagian belakang lidah ke arah dasar mulut serendah mungkin, sebalik standar I, sedangkan bibir berada dalam posisi netral. Standar ini menghasilkan vokal yang diberi lambang $/ a /$.

6. Standar VI. Vokal ini dibentuk dengan menaikkan bagian belakang lidah ke arah langit-langit tetapi lebih rendah dari standar VII, kira-kira $1 / 3$, sedangkan bibir berada dalam posisi semi membulat. Standar ini menghasilkan vokal yang diberi lambang / د /. Inilah yang dimaksud dengan imâlah sughrâ.

7. Standar VII. Vokal ini dibentuk dengan menaikkan bagian belakang lidah ke arah langit-langit tetapi lebih rendah dari standar VIII, kira-kira 1/3, sedangkan bibir berada dalam posisi semi membulat. Standar ini menghasilkan vokal yang diberi lambang /o/. Vokal inilah yang dimaksud dengan imâlah kubrâ dalam ilmu linguistik Arab.

8. Standar VIII. Vokal ini dibentuk dengan menaikkan bagian belakang lidah ke arah langit-langit setinggi mungkin. Standar ini menghasilkan sebuah bunyi yang diberi lambang / $\mathrm{u} /$.

9. Standar IX. Vokal ini dibentuk dengan menaikkan bagian tengah lidah ke arah langit-langit setinggi mungkin. Adapun bagian depan dan belakang lidah tetap pada posisi sentral (tidak tinggi dan tidak rendah), sedangkan kedua bibir berada dalam posisi netral (tidak membentang dan tidak membulat). Standar ini menghasilkan sebuah bunyi yang diberi lambang / $\partial$ /.

Tingkat ketinggian yang dicapai oleh bagian lidah yang bergerak juga sangat dominan dalam menentukan sebuah vokal. ${ }^{32}$ Dalam ilmu fonetik, tingkat ketinggian yang dicapai oleh lidah tersebut dibagi dalam empat bagian, yaitu: tinggi sekali, agak tinggi, agak rendah, dan rendah sekali. Keempat tingkat ketinggian bagian lidah dalam memproduksi vokal dapat diuraikan sebagai berikut.

Tingkat sangat tinggi. Ketentuannya: apabila bagian lidah depan naik tinggi sekali, maka vokal yang terjadi adalah vokal kasrah (i) dan apabila bagian lidah belakang naik tinggi sekali, maka vokal yang terjadi adalah dhammah (u).

Tingkat agak tinggi. Ketentuannya: apabila bagian lidah depan naik agak tinggi, maka vokal yang terjadi adalah vokal imâlah kubrâ (e) dan apabila bagian lidah belakang naik agak tinggi, maka vokal yang terjadi adalah imâlah kubrâ (o).

\footnotetext{
32 Kamal Muhammad Bisyr, op. cit., h.140.
} 
Tingkat agak rendah. Ketentuannya: apabila bagian lidah depan turun agak rendah, maka vokal yang terjadi adalah vokal imâlah sughrâ ( $\varepsilon$ ), dan apabila bagian lidah belakang turun agak rendah, maka vokal yang terjadi adalah imâlah sughrâ (ગ).

Tingkat rendah sekali. Ketentuannya: apabila bagian lidah depan turun rendah sekali, maka vokal yang terjadi adalah vokal fathah (a) dan bila bagian lidah belakang turun rendah sekali, maka vokal yang terjadi adalah fathah $(a)$.

Dari penjelasan di atas, dapat dipahami bahwa imâlah kubrâ adalah menuturkan vokal (e) sebagai ganti dari diftong (ai), sedangkan imâlah shugrâ adalah menuturkan vokal ( $\varepsilon$ ) sebagai ganti dari diftong (ai) yang keduanya dibentuk dengan mengangkat bagian depan lidah (bukan bagian belakang) ke atas dengan tingkat yang berbeda. Sedangkan sebagian penyusun ilmu qirâ'at malah menyatakan bahwa imâlah kubrâ adalah tafkhîm dan imâlah sughrâ adalah tarqîq-sebuah pernyataan yang sangat kabur, sulit diukur, bahkan justru menambah kerancuan.

Oleh karena itu, menurut penulis, penjelasan ilmu fonetik seperti di atas sebaiknya dimanfaatkan oleh para penyusun ilmu qirâ'at untuk menyempurnakan pengertian imâlah kubrâ yang ditakrifkan sebagai "menuturkan fathah dekat dengan kasrah dan alif dekat dengan yâ", dan imâlah sughrâ yang didefinisikan sebagai "menuturkan fathah antara fathah dengan imâlah kubrâ". Dengan memanfaatkan kajian (temuan) baru dalam fonetik, ilmu tajwid diharapkan semakin berkembang, mudah diaplikasikan, dan memiliki pengukuran yang akurat.

\section{Simpulan}

Perkembangan informasi dan teknologi di satu pihak serta globalisasi di pihak lain mengakibatkan batas antara ilmu pengetahuan dengan ilmu pengetahuan lain semakin kabur. Oleh sebab itu, suatu ilmu pengetahuan harus membuka diri terhadap ilmu lain agar ia dapat diterima dengan baik oleh generasi mendatang. Ilmu tajwid akan dapat lebih diterima dengan membuka diri terhadap penemuan ilmu fonetik, ilmu kedokteran, ilmu anatomi, dan lain sebagainya.

Ilmu tajwid dapat didorong untuk bersinergi dengan ilmu fonetik tanpa harus mereduksi apa yang telah diupayakan oleh ulama tajwid. Beberapa temuan fonetik yang mudah diaplikasikan dan terukur secara akurat dapat dimanfaatkan oleh ilmu tajwid untuk pengembangan keilmuannya dan aplikasi pembelajarannya.Sebab, dalamilmu tajwid masih terdapat beberapa problem peristilahan teknis ilmiah yang rancu dan perlu diperbarui, seperti makhraj bunyi, sifat bunyi, bunyi oral, nasal, dan oronasal, bunyi tebal dan tipis, serta imâlah dan fath (tahqîq), sebagaimana dipaparkan dalam tulisan ini. Lebih dari itu, masih banyak pula problem lain yang dapat dibahas dalam konteks menyinergikan ilmu tajwid dengan fonetik, seperti: izhhâr, idghâm, ikhfâ', iqlâb, qalqalah, madd, waqaf, dan nagham.

Berdasarkan pada temuan dan hasil kajian ilmu fonetik yang lebih akurat, penulis berpendapat bahwa ilmu tajwid sebaiknya segera memanfaatkan ilmu fonetik untuk pengembangan keilmuannya dan aplikasi pembelajarannya sehingga ilmu ini lebih ilmiah dan obyektif serta memudahkan orang-orang yang mempelajari bacaan alQur'an.[] 


\section{Daftar Rujukan}

Anbar, Tagrid Sa'id, Dirâsat Shautiyyah, Jilid I, Tunis: ALESCO, 1990.

Bisyr, Kamâl Muhammad, al-Ashwât al-'Arabiyah, Kairo: Maktabah Al-Syabâb, 1991.

Fathoni, Ahmad, Kaidah Qiraat Tujuh, Jakarta: PTIQ 2005.

al-Hallâwi, Muhammad Abdel Aziz, Kaifa Tujawwid al Qurân wa Turattiluhu Tartîla, Kairo: Maktabah al-Qurân, 1984.

Hamd, Qaddûrî, Beirut: Muassasah al-Risâlah, 1986.

Hanna, Sâmi Ayad, Mabâdi' 'Ilm al-Lisâniyat al-Hadîtsah, Alexandria: Dâr al-Ma'rifah alJâmi'iyah, 1991.

al-Jazarî, Ibn, al-Nasyr fi Qirâ'at al-'Asyr, Jilid I, Beirut: Dâr al Fikri, tt.

al-Khûlî, Muhammad 'Ali, Mu'jam 'Ilm al-Ashwât, Riyâdh: Maktabah al-Farazdaq, 1982.

al-Mahdî, Kamâl Muhammad, Tajwîd al-Qurân, Kairo: Dâr al-Taufîq, 1988.

Mahmûd, 'Abdullah Rabie, dkk., Ilm al-Shautiyyât, Makkah: Maktabat al-Thâlib al-Jâmi'i, Cet. II, 1988.

Nasution, Ahmad Sayuti Anshari, Bunyi Bahasa, Jakarta: Amzah, 2009.

al-Qâdhi, 'Abdul Fattâh Abdul Ghani, al-Wafi fi Syarh al-Syâthibiyah fi al-Qirâ'at al- Sab'i, alMadinah al-Munawarah: Maktabah al-Dâr, 1989.

Qamhâwî, Muhammad al-Shâdiq, al-Burhân fi Tajwîd al Qurân wa Fadhâil al Qurân, Kairo: Maktabah al Kulliyat al-Azhariyah, 1978.

Sa'udi, Ahmad Syirbinî, al-Fajr al Jadîd fi 'Ilm al-Tajwîd, Kairo: Dâr al-Manâr, 1990. 